\title{
Pandemi Sürecinde Vernaküler Mimaride Kolektif Çalışma “Muyinga Kütüphanesi"
}

\author{
Özgü ÖZTURAN ${ }^{1 *}$ (D) , Neslişah ÖZTÜRK ${ }^{2}$ (D) , Şebnem ERTAŞ BEŞiR ${ }^{3}$ \\ ORCID 1: 0000-0002-8639-5570 \\ ORCID 2: 0000-0002-8178-2467 \\ ORCID 3: 0000-0002-0568-6529 \\ ${ }^{1}$ Akdeniz Üniversitesi, Mimarlık Fakültesi, Iç Mimarlık Bölümü, 07070, Antalya, Türkiye. \\ ${ }^{2}$ Akdeniz Üniversitesi, Fen Bilimleri Enstitüsü, l̇ç Mimarlık Ana Bilim Dalı, 07070, Antalya, Türkiye. \\ ${ }^{3}$ Akdeniz Üniversitesi, Mimarlık Fakültesi, lç Mimarlık Bölümü, 07070, Antalya, Türkiye. \\ *e-mail: ozguozturan@akdeniz.edu.tr
}

Öz

2019 yılının sonlarında ilk olarak Çin'in Wuhan kentinde görülen, COVID-19 olarak adlandırılan Yeni Koronavirüs Hastalığı çok kısa sürede tüm dünyaya yayılmış, Dünya Sağlık Örgütü (WHO) tarafından pandemi olarak ilan edilmiştir. Toplum sağlığının korunması üzerine dünya çapında hükümetler tarafından bazı önlemler ve kısıtlamalar uygulanmıstırı. Ekonomik düzen ve eğitim sistemlerinde görülecek değişimlerin yanı sıra tarihsel açıdan derin köklere ve geniş anlamsal içeriğe sahip mimarlık kavramı da bu süreçte etkilenmiştir. Araştırmada Vernaküler mimarinin inşa sürecinde kolektif çalışmaların COVID-19 sürecinde sürdürülebilir olması amacıyla ne tür önlemlerin alınabileceğinin ortaya konulmuş; Afrika'nın Burundi ülkesindeki Muyinga kütüphanesinin pandemi süreci ile karşılaştırmalı incelemesine yer verilmiştir. Bu inceleme ile yeni koşullara uygunluk, dönüşümün varlığı ve değişim ihtiyacı örneklem çalışması üzerinden tartışmaya sunulmuștur.

Anahtar Kelimeler: Covid-19, pandemi, vernaküler mimari, kolektif çalışma

\section{Collective Work in Vernacular Architecture During The Pandemic Process "Muyinga Library"}

\begin{abstract}
The new coronavirus disease (COVID-19), which was first reported in Wuhan, China at the end of 2019 has spread to the world in a very short time. With the declaration of the pandemic by WHO, measures and restrictions have been implemented by governments worldwide. After all, it was recognized that in addition to the individuals and the existing health system, the global economic order and education system were also affected by the pandemic. In fact, it is predicted that even the concept of architecture will be affected. In the research, what kind of measures can be taken in order to ensure the sustainability of collective works in the construction process of the Vernacular architecture during the COVID-19 process was revealed; and the Muyinga library in Burundi, Africa, as an example of vernacular architecture has been analyzed in comparison with the pandemic process. Through this analysis, the existence of transformation, the possibility of adopting new conditions, and the need for change have been discussed.
\end{abstract}

Keywords: Covid-19, pandemic, vernacular architecture, collective work

Citation/Atıf: Özturan, Ö., Öztürk, N. and Ertaş Beşir, Ş. (2021). Pandemi sürecinde vernaküler mimaride kolektif çalışma "Muyinga Kütüphanesi”. Journal of Architectural Sciences and Applications, 6 (2), 404-413.

DOI: https://doi.org/10.30785/mbud.929826 


\section{Giriş}

2019 yılının sonlarında ilk olarak Çin'in Wuhan şehrinde görülen zatürre vakalarının ortaya çıkması ile 5 Ocak 2020 tarihinde yapılan incelemeler sonucunda Yeni Koronavirüs Hastalığı tanımlanmıştır. COVID-19 olarak adlandırılan, çok kısa sürede tüm dünyaya yayılan bu salgın hastalık, 12 Mart 2020 tarihinden itibaren Dünya Sağlık Örgütü (WHO) tarafından pandemi olarak ilan edilmiştir. Bu pandemi sürecinin ilanı ile birlikte, toplum sağlığının korunması üzerine dünya çapında hükümetler tarafından bazı önlemler ve kısıtlamalar uygulanmıştır. Alınan önlemler ve uygulanan kısıtlamalar sonucunda salgın hastalıktan etkilenenlerin sadece kişiler ve sağlık sisteminin olmadığı görülmüş, birçok hususun değişime uğrayacağı hakkında görüşler ve değerlendirmeler ortaya çıkmıştır. Bunlar; ekonomik düzen, eğitim sistemleri ve sağlık sistemlerinin dinamiksel olarak değişimlerinin yanında mimaride de birçok değişimi ve gelişimi içereceği öngörülmüştür.

Arslan ve Karagül'ün (2020) de belirttiği gibi; COVID-19 olarak adlandırılan yeni korona virüsü, sahip olduğumuz yaşamın olağan akışını etkileyen; bireysel, ulusal ve uluslararası düzeyler aralığında değişime sahip sonuçlar üretme kapasitesindedir. Bu değişim, tarihsel açıdan derin köklere ve geniş anlamsal içeriğe sahip olan mimarlık için de geçerlidir. Mimarlık hakkında yüzyıllar boyunca farklı tanımlamalar ve yorumlamalar insanlığın varoluşuna kadar temellendirilmiştir. İnsanoğlunun çevre ile etkileşimi sonucunda, dönemin dinamiğine göre mimarlığın şekillendiği kanısına varılmıştır. COVID-19 salgını sebebi ile sağlık tehdidiyle karşı karşıya kalan toplumsal düzenin dinamiğinin değişmesi ve dönüşüme uğraması, mimarlık kavramının ve içerdiği alt dalların etkili değişim ve dönüşümüne neden olacağı tahmin edilmektedir.

Çalışmada, salgın bir hastalığın varlığı sonucunda değişim ve dönüşümün inceleneceği bir mimarlık dalı olarak vernaküler mimari; Latince "vernaculüs" sözcüğünden türeyerek ilk kez 1861 yılında kullanılmıştır (Şuta, 2019). Eyüce (2005) tarafından vernaküler mimari, yerli ya da bir yere özgü anlamını içeren bu mimarlık kavramı, yerel ihtiyaçlar ve yapım malzemeleri ile gelenekleri yansıtan kendine özgü bir mimari biçimlenme dili olarak tanımlanmıştır (Şuta, 2019). Süreç içerisinde bulunduğu çevreyi kendi ihtiyaç, istek ve olanaklarına göre şekillendiren insanoğlu, bunu anonim veya kolektif bir şekilde sağlamış, bölgeye ait iklim, kültür, malzeme gibi unsurları mimari ögelere katarak vernaküler mimarinin doğmasında etken bir rol oynamıştır. Yerel kültürel unsurları yeniden canlandıran vernaküler mimarinin doğması kısaca sosyo-coğrafi ve kültürel ihtiyaçlara dayandırılmıştır (Janetius, 2020). Bektaş'a (2001) göre; "Sonunda bir yapının bulunduğu yol, kullanıcının gereksiniminden başlar. Gereksinimin türü, boyutu; kişiye, yaşama kültürüne, yaşama biçimine, toplum yapısına, ilişkilerine göre değişir. Gereksinim yaşam içinde değişir... üretebilir de... ".

Vernaküler mimari, yerel gelenekleri ve kültürel uygulamaları yansıttığı gibi aynı zamanda da kolektif bir çalışmanın ürünüdür. Bu ürünün, halkın yaşama biçimini ve kültürünü yansıtması ise onun yani halkın katılımı ile olur. Ortak bir hedefe ulaşmak için birlikte, ortaklaşa yapılan çalışmayı kapsayan kolektif çalışma, yerel halkın kendi imkanları doğrultusunda yapıyı inşa etmelerinin yanında tasarım aşamasında özellikle de yerel toplumların doğrudan katılımını içermektedir. Bu kapsamda; vernaküler mimari için kolektif çalışma sosyoekonomik yaşamdan, eğitim, sağlık ve sosyokültürel alanlarda değişim ve dönüşümlere yol açan salgın bir hastalık ile karşı karşıya kaldığımız bu süreçte de mümkün müdür? Bu gibi sorulara yanıt aradığımız bu çalışmada vernaküler mimarlığın amacı olan iklim, mimarlık ve insanlar arasındaki ilişkisinin, yeni koronavirüs hastalığının (COVID-19) varlığı ile değerlendirilmesi gerçekleştirilmiştir. Afrika'nın Burundi Cumhuriyeti'nde, yerel halk ile birlikte tasarlanan bir kütüphane incelemesi üzerinden örneklem çalışması yapılarak, salgın hastalık sonucu dinamiksel olarak değişim gösterecek bazı temel özelliklerin neler olduğu üzerine durulmuştur. Bunlardan biri olan vernaküler mimarlıkta yer alan kolektif çalışmanın nasıl gerçekleşeceği; gereksinimlere, dönüşümlere ve gelişmelere bağılı olarak ele alınması hedeflenmiştir.

\subsection{Vernaküler Mimari}

Mimarlık için "vernaküler" teriminin kullanımı, dilbilimsel bir analojiye dayanmaktadır. Dilbilimde "yerel" dil, belirli bir bölgenin karakteristik dilidir (Kavas, 2015). Günlük hayatın dilsel kalıplarında farklı bir kültürel kimliğin kodlandığı varsayılmaktadır. Zaman içerisinde bu terim, kültürel kimlik ile gündelik 
yaşamın sahip olduğu mimari kalıplar ile kodlanarak mimarlık alanında yeni bir oluşumu temsil etmiştir (Kavas, 2015). Kültürel kimlik, insanoğlunun psikolojik ve sosyal sürecinin bir yansıması olarak alışkanlıkları, inançları, davranış biçimlerinin yanında oluşturduğu araçları ve mekânları da kapsamaktadır. Yerel kültür ise bizlere günlük yaşamın farklı alanları hakkında bilgi verirken, mimari ile etkileşime geçerek insan, doğa ve yapı arasında bütünlük kurar. Bu bütünlüğün yapı türleri, formları, gelenekleri, kullanımı ve bu gibi benzeri bağlamlarda çok büyük bir aralığı kapsamak için kullanılır (Paköz, 2017). Uluslararası bir değer kazanmış olan vernaküler mimarinin tanımı ise ansiklopedik mimarlık sözlüğünde Hasol (2014) tarafından; halkın kendi çevresinden sağladığı malzeme ile yerel geleneksel teknikleri ve biçimlerin varlığından yararlanarak gerçekleştirdiği bir çeşit anonim mimarlık, yöresel mimarlık olarak tanımlanmıştır. Türkiye'de mimarlık alanında yapılan bazı çalışmalara bakıldığında ise vernaküler mimarlık ile ilgili bazı kavramlara ulaşılmıştır. Bunlar; sivil mimari, geleneksel mimarlık, yerel mimarlık, Türk Evi, Osmanlı Evi ve halk yapı sanatı olarak örneklendirilmekte ve bu kavramların ise belirli bir yerdeki geleneksel yapıların tanımlamalarını yapmak için araştırmalarda sıklıkla kullanıldığı görülmektedir (Paköz, 2017).

Bir bölgeye özgü yöresel dili ve özgün kültürel karakteri ifade eden "vernaküler" kavramı, mekânsal kalıpların kültürel kimliği ile kodlanmasıdır. Bu kodlar nesiller boyunca aktarılır ve mimari bir gelenek oluşturur (Kavas, 2015). Bu gelenek ise "vernaküler mimarlık" olarak karşımıza çıkar. Dünyanın farklı coğrafyalarında vernaküler mimari oluşumlarının görülmesinin bir diğer sebebi doğal koşullar, yerel yapı malzemeleri ve teknikler olduğu kadar kültürel kimlikler de gösterilebilir. Bunlar arasında toplumsal değerler, doğayı algılama biçimlerini ve doğa ile insan arasındaki ilişkiyi de belirleyerek yapılı çevrelerin oluşumunda rol oynamaktadır (Canan, Kobya, Aköz ve Temiz, 2020).

Kullanıcının kimliğini, kültürünü ve yaşam biçimini yansıtan genel girdiler vernaküler mimarinin oluşumunda esastır (Ertaş Beşir ve Bekar, 2020). Bu girdiler sınırlayıcı olduğu kadar, mekânsal ve yapıya ilişkin teknik sorunların çözümünde ilerleme sağlayarak, yaratıcılığı kuvvetlendirmiştir. Bir yerin doğal özelliklerini, öncelikle iklimsel koşullar, bitki örtüsü ve topoğraf gibi çeşitli etkenler belirlerken, benzer iklimsel özelliklerine kıyasla, dünyanın birçok farklı coğrafyalarında yapı üretim şekillerinde benzerlikler kadar farklılıklar da görülebilmektedir (Canan vd., 2020). Mekânsal ve yapıya ilişkin teknik sorunların çözümünde her zaman çok seçeneğe sahip olmayan vernaküler mimarlık, bilgece çözümlemelere ek olarak değişme ve gelişme özelliğine sahiptir. Zaman içinde bulunduğu çevresel, kültürel, teknolojik ve tarihsel bağlamı yansıtacak şekilde var olan bir olgudur.

Sezgin (1984) yapmış olduğu bir çalışmada, "vernaküler" olarak tanımlanan yapıyı oluşturan ve katkılarının çokluğuna vurgu yapan ilkel (primitif) ve oluştuğu yerde yaşamını sürdüren (ingene, indigenous) mimarilerinden bahsetmektedir. Bu primitif terimi ile ilkellik bağlamında bir düzeyden bahsedilir. Herkesin kendi konutunu basit teknikler ile inşa edebildiği diğer ingene mimari ise aslında bir gelişim sürecinde yer alan kültürün bilinçsiz olarak ifade edilmesidir. Bu iki mimaride de bina ya da çevre, mimar veya başka bir sanatçı vasıtası ile elde edilmemektedir. Her ikisinde de yapılar, onları kullanan kişiler ya da teknik detaylar konusunda daha iyi olan zanaatkar ile yapılan iş birliğinin birer sonucu olarak bilinmektedir. Bunlara ek olarak yapıyı ortaya koyan kişi ya da kişilerde geleneksel kurallara uyma ve kullanılacak malzemeler konusunda bilgi sahibi olma durumu görülür (Sezgin, 1984). Kavramın tam olarak belirlenmesi için Sezgin (1984) vernaküler mimari'nin özelliklerini şöyle sıralar;

- Vernaküler mimari'de herhangi bir tasarımın ve ifadenin yöntemi yoktur. Yapıda uygulanan strüktür ve yapı malzemesi, binanın formunu belirler. Bu durum herhangi bir teorik iddianın bulunmayışını da ortaya koymaktadır.

- Yapılarda strüktür ve teknoloji farklılıkları görülebilir. Ancak yapı malzemesi her zaman doğaldır.

- Yapı basittir. Buna ek olarak kesin ve anlaşılması kolaydır.

- Vernaküler yapılar genellikle, ekleme ve yapışık şekillerde büyüyebilme özelliklerine sahiptir. Vernaküler yapılarda iklime ve doğaya uyma ve onlarla bütünleşme özellikleri görülür. 
- Vernaküler binaların yapımında başka kimselerin haklarına ve diğer objelere saygı gösterilmesi geleneklerin gereği olarak doğaldır.

- Estetik kalite her bina için ayrı ayrı oluşturulmaz. Bu geleneksel bir olay olarak görüldüğü için nesilden nesile devredilir.

Yapılan tüm araştırma çerçevesinde, vernaküler mimari, günümüz ve gelecek mimarlığında çevreye duyarlı bir mimari yaklaşımların oluşması için müracaat edilebilecek ve nitelikli oluşumlar içeren bir bilgi kaynağı olmuştur. Dolayısıyla vernaküler mimarinin içermiş olduğu bu nitelikler, sahip olduğu çeşitli yapım teknikleri ve malzeme özellikleri ile ekolojik yöntemlerin çağdaş konutlara örnek olarak daha sürdürülebilir mekanların ortaya konulması açısından oldukça önem taşımaktadır (Canan vd., 2020).

\subsection{Vernaküler Mimaride Kolektif Çalışma}

Kolektif kelimesi Türk Dil Kurumu'na göre: Birçok kimseyi veya nesneyi içine alan, birçok kişi ve nesnenin bir araya gelmesi sonucu olan, ortaklaşa olarak tanımlanır (TDK, 2021). Fransızca "collectif" yani "toplu, ortak" sözcüğünden alıntılanmış olup, Latince "colligere, collect" fiilinden türemiştir ("Kolektif ne demek", 2020). Kolektif kelimesi; kolektif çalışma, kolektif şirket, kolektif bilinç, kolektif güç, kolektif eğitim gibi birçok alanda karşımıza çıkmaktadır ("Kolektif yaşam nasıl olmalı", 2020). İşbirliğini ve ortaklaşa yapılan her türlü faaliyeti içeren bir takım çalışmasıdır. Takım çalışması, ekip çalışması, grup dinamiği gibi çeşitli başlıklar altında ifade edilebilen kolektif çalışma anlayışı, çoğulcu bir anlayış içererek, bireylerin bir arada uyumlu bir şekilde çalışmasını ve hedef birliği sağlayan ortak amaca birlikte ulaşmayı ifade etmektedir (Alaç, 2013). Kolektif bir çalışmada ortak bir isim altında toplanmak tekilliği, homojen ve birleşik bir işleyiş içinde anonim bir bünyede ortaya çıkarmaktır. Kolektif deneyim kabaca ortak bir direnç noktası belirlenerek harekete geçirilen, müşterek hedefin ve ortak yolların belirlendiği, amaçlı bir model halidir (Terkol, 2008). İş birliği ve kolektif düşünme ile her bireyin veya grubun aktif bir katılımcı olduğu görüşü ortaya çıkar. Buradaki bireyin veya toplumun amacı bilgiyi paylaşmak, topluluklar kurmak ve "etki" odaklı işler yapmak olabilirken, bir deneyim olarak onu sunmak da olabilmektedir. Tüm bu bilgiler dahilinde kolektif çalışmaya bir örnek verilmesi gerekir ise; geçmişten bugüne içinde bulunduğu çevre ile sürekli iletişim halinde olan insanoğlunun dahil olduğu ortaklaşa yapılan her türlü faaliyet verilebilmektedir.

İnsanoğlu süreç içerisinde bulunduğu çevreyi kendisine göre düzenlemeye başlamış; tarım dönemine kadar taş, ahşap, bitki gibi malzemeleri şekillendirerek kullanırken, dönemin ilkel toplumlarında gereksinimlerin karşılanmasına ek olarak iş bölümünün varlığı ile kendi yaşam alanlarını inşa etmiştir (Aytis ve Ozcam, 2010). Burada insanoğlu kendi evinin mimarıdır. Süreç içerisinde bahsi geçen "kendi evinin mimarı" tanımı, insanoğlunun toplumsal etkileşim, gelişim ve dönüşümleri ile yeniden şekillenmiş, zamana ve kültüre bağlı olarak ortaya çıkan bu oluşuma ek olarak, eylem ve organizasyon şemasında da çeşitli değişimler ile karşılaşmışır.

Vernaküler mimari, bir diğer ismi ile geleneksel mimarlık; tarih süresince insanın çevresi ile doğrudan olan ilişki ve deneyiminden kaynaklanarak, çevre koşullarına en uygun şekilde çözümler üreten ve yaşam kültürünü yansıtan, insan, doğa ve kültür bütünü olarak tanımlanır (Yeler ve Özek, 2017). Vernaküler mimaride bu yapılar, toplumun ortak inançları ve yaşayışlarına göre zaman içinde şekillenmektedir. İçerisinde bulunduğumuz dönemdeki gibi özel mimarlar veya mühendisler tarafından değil, yerel sahipler ve bölgedeki ustalar tarafından, anonim olarak yapılmaktadır (Aytis ve Ozcam, 2010). Vernaküler mimaride insanların, çevresel entegrasyon için çözümler geliştirmek için doğal süreçlere aktif olarak katıldığı bilinmektedir. Bu fiziksel katılımlarda tüm duyular yoğun bir şekilde kullanılmış, çağdaş mimarlık pratiğinin aksine, yerel tasarım ve inşaat, doğaçlama ve dokunsal duyuları kucaklayan iç içe geçmiş bir aşama olarak sunulmuştur (Kavas, 2015). Bu duyuların kullanımı ile toplumun veya bireyin sahip olduğu kültür, doğrudan veyahut bilinçsiz bir şekilde vernaküler mimari ürününe yani maddeye dönüşür.

Modern mimaride, mühendisliğin ve profesyonellerin katılımından bahsedilirken, yerel yapı olarak vernaküler mimaride profesyonel uygulamalardan daha çok ilkel ve basit inşaat teknikleri görülmektedir. Basit inşaat tekniklerini gerçekleştirenler ise, eğitimli mimarlar değil; tasarım 
becerisine, yeteneklerine ve geleneklerine bağlı yerel halktı. Bazen isimleriyle, bazen anonim olarak bilinen bu kişiler, binaları planlar ve inşa ederlerdi. Modern mimarinin aksine geleneksel mimari, çok katkılı, mimarı belli olmayan, biri diğerinin etkileyicisi ve köklendiricisi olan yapılar birliği olarak tanımlanmış ve yapılardaki anonim özelliği ile ön plana çıkmıştır (Şen, 1968). Bunun sebebi, vernaküler mimaride yapıların, günümüzdeki gibi belirli bir kişi tarafından ya da yaklaşımlar aracılığı ile oluşmayıp, toplumun ortak inançları ve yasayışlarına göre şekillenen, yerel bölgede yaşayan ustalar ve halkın katılımı ile kolektif bir oluşum içermesi olmuştur.

\section{Materyal ve Yöntem}

Vernaküler mimarinin inşa sürecinde kolektif çalışmaların COVID-19 sürecinde sürdürülebilir olması amacıyla ne tür önlemlerin alınabileceğinin ortaya konulduğu çalışmada; pandemi öncesi yapılan çalışmalar irdelenerek salgınla birlikte yapılamayacak eylemler tespit edilmiştir. Literatür taramasına dayalı araştırma, pandemi öncesi ve bu süreçte bir kolektif çalışma örneği olarak "Muyinga Kütüphanesi" örneği üzerinden inşa yapımına ait hem eylemler hem de katılımcılar açısından koşullar kıyaslanarak tanımlanmıştır.

\subsection{Vernaküler Mimaride Kolektif Çalışma Örneği Olarak " Muyinga Kütüphanesi"}

Muyinga kütüphanesi, duyma engelli çocuklar için kapsayıc bir yatılı okul olarak Muyinga 'da kamu altyapısı aracılığıyla inşa edilmiş onları topluma entegre etmeyi planlayan bir projedir. Belçika'da yer alan bir mimarlık stüdyosu olarak "BC Architects and Studies" tarafından 2012 yılında $140 \mathrm{~m}^{2}$ alana inşa edilmiştir. Mimarlık stüdyosu üyelerinin "hayatta kalma ihtiyaçlarının bizlere mimarlığın anlamını öğrettiği yer" olarak tanımladıkları Afrika'nın Burundi şehrinde inşa edilen bu kütüphane, gelecekte işitme engelli çocuklar için yapılacak okul; yerel kaynaklı sıkıştırılmıs toprak bloklarla ve kolektif bir çalışma yaklaşımı ile inşa edilmiştir. Güncel mimari bilgiyi geride bırakarak inşa edilen bu yapıda mimarlar, zanaatkarlar ve halktan insanlar çalışmış, yapıda yerel malzeme özelliklerinin mekâna ilham vermesine izin verilmiştir. Vernaküler mimarinin özelliklerini taşıyan bu yapıda, yerel iklim ve kullanıcı intiyaçları göz önünde bulundurulmasının yanında Burundi'deki yerel mimari uygulamalarının kapsamlı incelenmesi de tasarımın temelini oluşturmuştur. Bölgede gerçekleştirilen iki aylık saha çalışması sonunda, yerel malzemeler, teknikler ve bina tipolojileri hakkında toplanan bilgi ile halkın bilgi birikimi ve gelenekleri; yapıya yeniden yorumlanarak uygulanmıştır (Şekil 1). Bu süreçte, kütüphanenin inşasında yalnızca bir yapının oluşumunu değil, o yapı çevresindeki yaşam döngüsünün çevresel, kültürel ve geleneksel bağlamını da incelememize de katkı sağlamaktadır (B.C. Architect and Studies, 2012a).
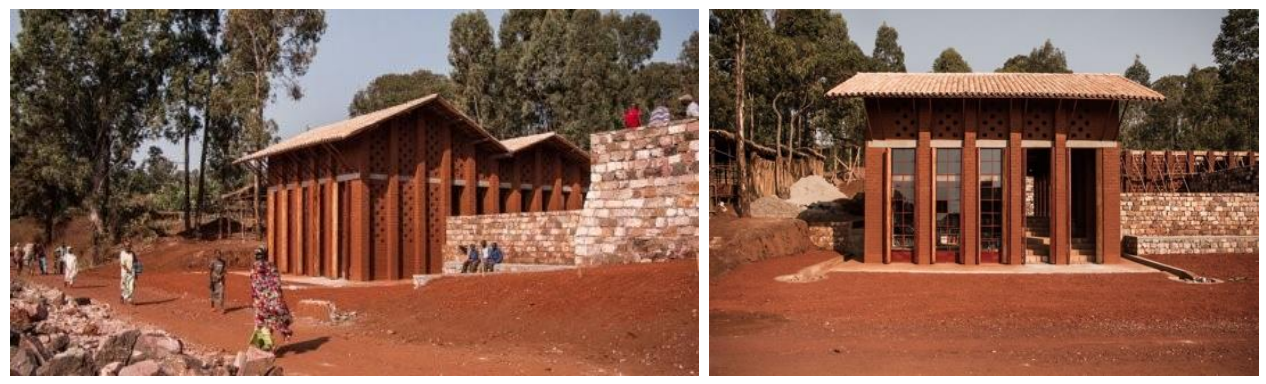

Şekil 1. Muyinga Kütüphanesi görünüşleri (B.C. Architect and Studies, 2012b)

Yapının mimarisine bakıldığında toprağın yükselişi ve devamlılı̆ının belirginliğine ek olarak kullanılan malzeme yerelliğinin, şehrin sahip olduğu iklimsel özelliklerin ve geleneklerin bir sunumudur. Kütüphane kapalı bir dolaşım alanı etrafında düzenlenmiş ve "revak" adı verilen güneşten ya da yağmurdan korunma amaçlı işlevsel sundurmalara sahiptir (B.C. Architect and Studies, 2012a) (Şekil 2). 

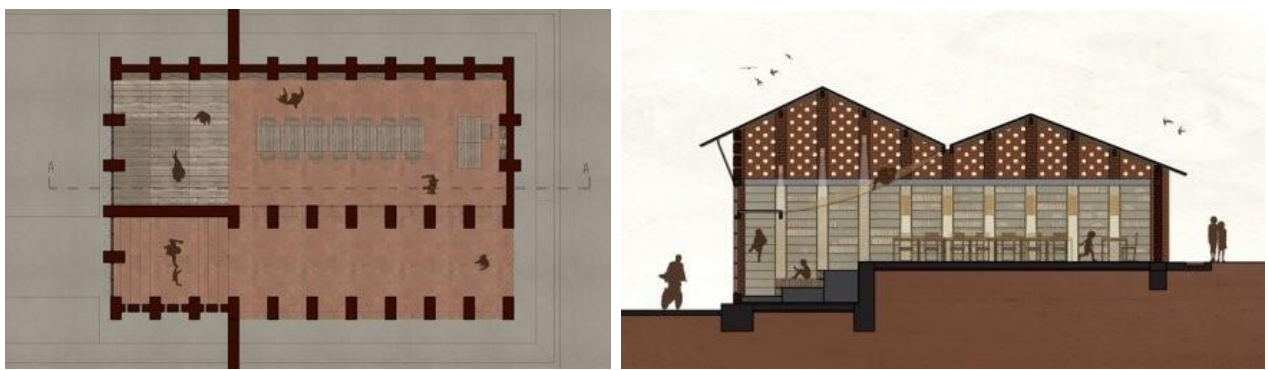

Şekil 2. Muyinga Kütüphanesi plan ve kesit (B.C. Architect and Studies, 2012b)

Sıkışırılmış toprak bloklar ve pismiş toprak kiremitten meydana gelen kütüphanenin genel formu incelendiğinde ise; kütüphanenin yüksek duvarları için destek görevi gören, 130 santimetre aralıklarla sütunların yapısal sisteme eklenmiştir. Sütunların oluşturduğu bu ritmik tekrar, binanın hem içerisinde hem de dışında etkisini göstermektedir. Çatı ise, fırınlanmamış CEB (Compressed Eearth Block) bloklarını korumak için \%35'lik bir eğime sahiptir. Burada CEB olarak adlandırılan bloklar, belli oranda ve türde nemli toprağın basit makinalar ile sıkıştırılarak inşa yapılabilecek blok haline getirilmiş halidir. Tasarım, CEB'i, toprağa olan ilgiyi simgelemek ve onun potansiyelini ortaya çıkarmak için kullanmışlardır. Bir diğer amaç ise, betonun yapısal kullanımını en aza indirgemektir. Hem betonun yapısal kullanımını azaltmak hem de yapısal bir risk almak istemeyen tasarımcılar, sadece CEB blokları ile oluşturdukları kolonların içerisine beton iskelet yapısı konumlanmıştır. İklimsel düşüncelerin tasarıma etkisi ise; havalandırmanın mümkün kılındığı, çapraz havalandırmalı yüksek bir iç mekânın tasarlanması ile sağlanmıştır. Tasarlanan iç mekân nemli ve sıcak havayı uzaklaştırmak için kullanıcıya yardımcı olmaktadır. Buna ek olarak cephede sıkıştırılmış toprak blokları (CEB) duvar işçileri tarafından ritimli bir şekilde delinmiş ve kütüphanenin gece görüntüsü oluşturulmuştur (Şekil 3). Sıkıştııılmış toprak bloklarındaki bu delinmelerin bir diğer örnekleri bölgenin geleneksel yapılarında da rastlanmaktadır (B.C. Architect and Studies, 2012a).
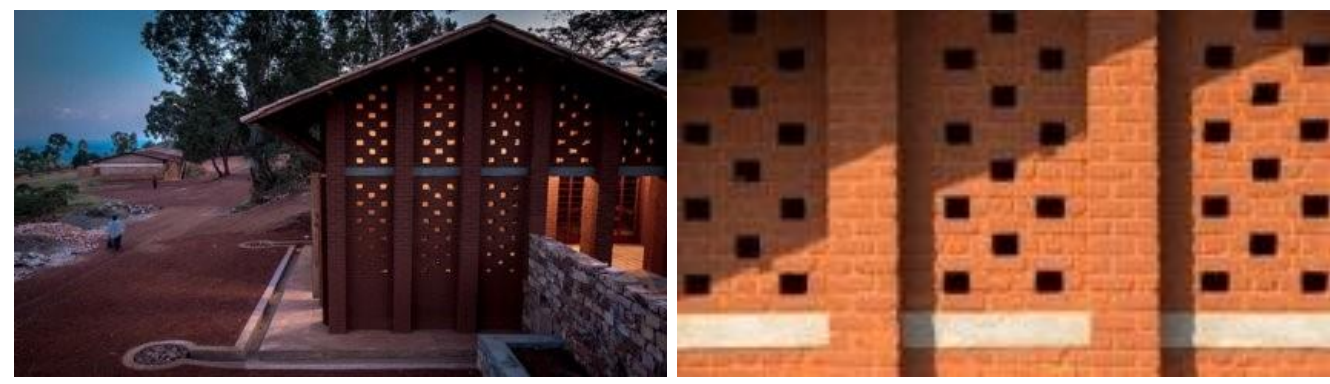

Şekil 3. Muyinga Kütüphanesi CEB kullanımı (B.C. Architect and Studies, 2012b)

Yapının cadde tarafına bakan iç mekanında kütüphanenin en küçük ziyaretçileri için ahşaptan oturma alanı oluşturulmuştur. Burada aynı zamanda grup okuma alanı olarak kullanılmaktadır. Ayrıca aynı mekanda Afrika'nın sıcak ve nemli ikliminde yetişen, çok elyafı yapraklardan oluşan Sisal (Agave sisalana) bitkisinden oluşan devasa bir hamak yerleştirilmiştir (Şekil 4) (BC Architects and Studies, 2012a).
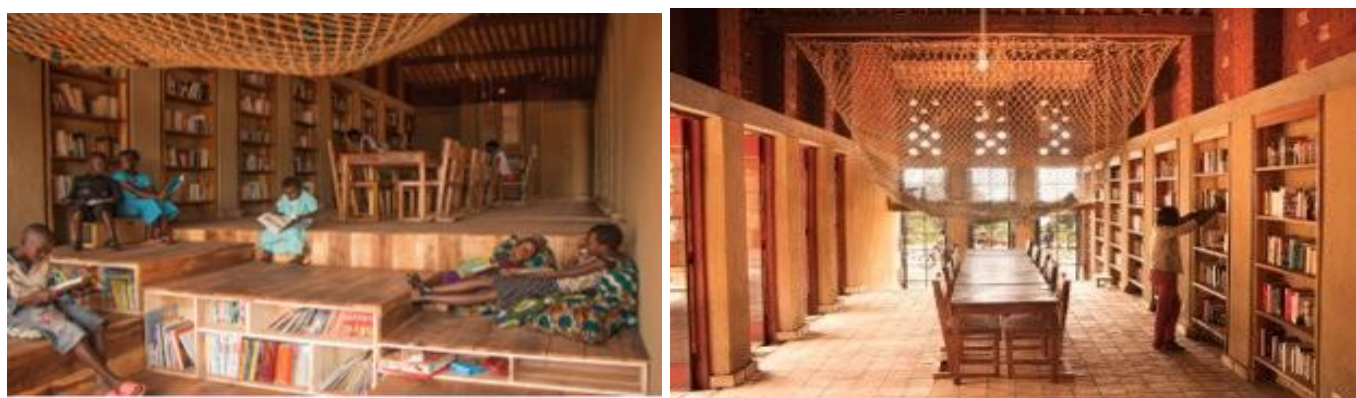

Şekil 4. Muyinga Kütüphanesi iç mekân (B.C. Architect and Studies, 2012b)

Görüldüğg̈ üzere, malzeme seçimleri tüm yapıyı şekillendirmektedir, bu kapsamda çatıyı destekleyen kirişlerin, Muramba'da sürdürülebilir şekilde hasat edilen Okaliptüs ağacından yapılmakta; çatı altyapısı 
ve çatı yüzeyinde yaklaşık 1400 adet bulunan kiremidin ithal oluklu saçların yerini alması, yerel malzemelerin kullanımını yeni bir tasarım öğesi olarak yeniden değerlenebileceğini kanıtlar niteliktedir.

Tüm bu bilgiler dahilinde ortaya çıkan yapı, ulaşılabilir ve yeniden tanımlanan bir mimari tarzı bizlere sunmaktadır. Yeni yöntemlerden ziyade eski yöntemlere, geleneksele kucak açmış bir usta-iş̧̧i kavramıyla hareket eden vernaküler mimarinin izlerini taşımaktadır. Kütüphanenin yapım anlayışında mimarlık bir stil değil bir ifade olarak, "ben" değil "biz" oluşumunu içermekte olan bir bağlamdır.

\section{Araştırma Bulguları}

\subsection{Kolektif Çalışma Örneği Olarak 'Muyinga Kütüphanesinin Pandemi Öncesi ve Süreci Boyunca Eylemler ve Katılımcılar Açısından Karşılaştırmalı İncelenmesi'}

Kolektif çalışma, modern mimaride önemli bir rol üstlenmektedir. Çoğu zaman teoriyi gerçek yaşam pratiğine çevirmek güç olsa da BC mimarları ve çalışmaları, inşaat uygulamalarında katılımcı süreçlerin uygulanmasına odaklanmışır. Bu uygulamalardan birisi olan Muyinga kütüphanesi, Belçika'da kâr amacı gütmeyen bir kuruluş olan SATIMO'nun finansal desteği, Afrika'da duyma engelli olan insanlara yardım eden bir kuruluş olan SHC'nin ve diğer birçok ortaklıkların varlığı ile meydana gelen, eğitim yapılarının gelişimine odaklanan özel bir yaklaşımın ürünüdür. Muyinga Kütüphanesi üzerinde yapılan kapsamlı bir inceleme ile inşaat ve tasarım sürecinin bir kolektif çalışma sürecini simgelediği görülmüştür. Bu yapıda uluslararası iş birliklerinin yanı sıra, yerel ustaların, yerel iş̧̧ilerin ve tasarım grubu üyelerinin ortaklaşa çalışmalarını kapsamaktadır. Bu ortaklaşa çalışma süreci yerel işgücü ile iş birliğine ek olarak öğrencileri, stajyerleri ve genç mimarları ortak bir eğitim ortamına dahil etmiştir. Örnek olarak Brüksel Luca Üniversitesi ile her yıl yaz okulu süresince gönderilen 3 ila 6 öğrenci, VLIR-UOS bursu ile desteklenerek Burundi'deki sahada en az 6 hafta çalışma şansı yakalamakta ve her yıl Zevenkerken Lisesi adına 2 haftalık deneyim gezileri düzenlenmektedir. Mimarlık stajları dahilinde her yıl 1 ya da 2 kişi en az 1 aylık süre dahilinde kolektif çalışmaya dahil olmaktadır. Hangi grup üyesi dahilinde olunur ise olunsun, CEB üretimi, kerpiç üretimi, toprak analizi, bambu dokuma, sisal dokuma, temel çözümler, mobilya tasarımı gibi çeşitli konularda analiz ve çalışma atölyelerine katılarak kolektif çalışma sürecine dahil olunmaktadır. Bu çalışma süreci yerel zanaatkarlara saygıyı içererek, bilgi alışverişinin oluşmasına katkıda bulunarak, küreselleşen bu dünyada gerçekleşen eylemlerin doğrudan sosyal, kültürel, ekolojik ve ekonomik etkilerinin anlaşılmasını sağlayan küçük ölçekli ama etkili bir kültürlerarası oluşumu meydana getirmiştir (B.C. Architect and Studies, 2012c).

Ancak dünyada var olan her olayın ve oluşumun değişebilirliğini gözler önüne sunan salgın bir hastalık ile karşı karşıya kaldığımız şu süreçte, bu oluşumun meydana gelmesi ne kadar mümkün olacaktır? Bu kolektif çalışma prensibinin sürdürebilirliğine değinilmek istenir ise: 2019 yılı sonu itibari ile ortaya çıkan COVID-19 salgını, toplumsal yaşam biçimlerini değişime uğratarak, bir dönüşüm ve yeni koşullara uygun standartların oluşma sürecini başlatmıştır. Dış dünya ile iletişim asgari düzeye inmiş, "kişisel izolasyon" adı altında karantina uygulamaları gerçekleştirilmiştir. Fiziksel mesafenin korunması amaçı "sosyal mesafe" kavramı hayatımıza girmiş, yeni kurallar ile gündelik yaşamımız değişime uğramıştır. Toplumsal yaşam biçimlerinde meydana gelen değişimlere ek olarak, eğitim, sağlık ve sosyoekonomik alanlardan, mimari ve tasarım sürecine kadar uzanan yeni oluşumlar gözlemlenmiştir.

Yukarıdaki sorunun cevabı olarak yapılan incelemeler göz önünde bulunarak; Muyinga kütüphanesinin yapı aşamasından tasarım aşamasına kadar olan zaman diliminde, çeşitli malzemelere erişimden, şantiyede çalışan işçilerin ulaşımına kadar çözülmesi gereken bazı problemlerin oluşabileceği öngörülmektedir. Yapı sürecinde, yerel bir ustabaşı/mimar olan yerel işçilerin çalışmaya dahil olduğu ve mimarlık öğrencileri ile iş birliği oluşturulmuştur. Ancak, yapı süreci pandemi sürecine dönüştüğünde, iş̧̧ilerin ve mimarlık öğrencilerinin birlikteliğinin sekmeye uğrayacağı, okullar tarafından yapılan ziyaretlerin bir kısıtlama içerebileceği hatta planlananın aksine bir sonuç doğurabileceği ön görülmektedir. 12 iş̧̧iden oluşan yerel iş̧̧i sayısında kişi sınırlandırılmasına gidilmesi, çeşitli ülkelerden staj adı altında çalışmaya katılan mimarlık öğrencilerin yurtdışı çıkış yasakları veya kısıtlamalardan dolayı çalışmaya dahil olamamaları gibi durumların gerçekleşmesi olağan olarak görülmektedir. 
Bunlara ek olarak önceliklerin değişmesi; sağlığa yapılan yatırım ve destekler dahilinde, finansal ve işgücü desteğinde azalmalar ve kısıtlamalar ile karşılaşılabilme durumu söz konusu olacaktır. Malzeme araştırmaları, tasarım kararları ve şantiye organizasyonu yapılırken uyulması gereken kuralların düzenlenmesi gerekecek ve iş bölümü olabildiğince asgari düzeye indirilmiş olacaktır. Salgının varlığı süresince proje yürütülürken, sosyal mesafe ve hijyen kurallarına da uyulması gerekecektir. Gerek CEB üretimi, kerpiç üretimi ve toprak analiz aşamasında gerekse çeşitli konularda yapılan çalışma atölyelerinde gerekli hijyen tedbirlerinin alınması şart olacaktır. Alınan tüm bu önlemler finansal açıdan proje yöneticilerini etkileyecek ve yapılan harcamalarda kısıtlamalar da görülebilecektir. İnşa ve tasarım sürecinde yer alan her katılımcı için, başlangıçtan itibaren düzenli aralıklar ile virüsü saptamaya yönelik PCR testlerinin yapılması önerisi sunulabilirken, yeterli finans kaynağı ve sağlık ekipmanlarının gerekliliği öngörülmektedir. Fakat Afrika gibi yoksulluk ile mücadele eden bir ülkede bu gerekliliklerin sağlanması için daha farklı çalışmaların gerçekleşmesi gerektiği aşikardır. Bu öngörülen çalışmalar ayrı tutularak, kolektif çalışmanın mümkün olup olmadığı sorusunun cevabı kesin değildir. Ancak çalışma içerisinde yer alan tüm katılımcıların gerekli kuralları uygulamaları dahilinde mümkün kılınabileceğine inanılmaktadır.

Bu doğrultuda, COVID-19 olarak adlandıılan yeni korona virüs hastalığının şekillendirdiği yeni süreç ve yapılandırmaların sadece bireyleri ve mevcut sağlık sistemini etkilemediği bilinmektedir. Buna ek olarak ekonomik düzen ve eğitim sistemlerinde görülen değişimlerin yanında mimarlık kavramında ve içermiş olduğu alt dallarında da değişim ve dönüşümlere sebep olacağı görülmüştür.

\section{Sonuç ve Öneriler}

COVID-19, insan yaşamında zamana ve kültüre bağlı olarak gerçekleşen gelişim ve dönüşümüne ek bir dönüm noktası olarak karşımıza çıkmıştır. Dünya'nın her toplumunu etkisi altına alan bu virüs; yaşam, çalışma, beslenme ve eğlence biçimlerinde yeni oluşum koşullarının sağlanması gerekliliğini gözler önüne sermiştir. Bu çalışmada ise, COVID-19'un varlığı ile yeniden şekillenen yapı inşa süreci üzerine bazı indirgemeler; vernaküler mimaride kolektif çalışma örneği ele alınarak yapılmış ve bireylerin ve grubun aktif katılımcı rol oluşumları üzerinde durulmuştur. Bu oluşumlar incelenirken, 2019 yılı sonunda ortaya çıkan bu salgının varlığı kabul edilerek sürdürülebilirliği üzerinde bir tartışma konusu oluşturulmuştur. Yeni koşullara uygunluk, dönüşümün varlığı ve değişim ihtiyacının altı çizilmiş, gerekli koşullar belirlenmiştir. iş̧ birliği içinde meydana gelen kolektif çalışma örneklerinin pandemi ile birlikte devam edebilmesi amacıyla, ne gibi önlemler alınması gerektiği maddelenmiş ve pandemi öncesi ile kıyaslama yapılarak aşağıdaki tabloda verilmiştir (Çizelge 1).

Çizelge 1. Kolektif çalışmaya yönelik pandemi öncesi ve sonrası koşulların değerlendirmesi

\begin{tabular}{|c|c|}
\hline $\begin{array}{l}\text { Kolektif Çalışmaya Yönelik Pandemi Öncesi Koşulların } \\
\text { Değerlendirmesi }\end{array}$ & $\begin{array}{l}\text { Kolektif Çalışmaya Yönelik Öngörülen Pandemi Koşulların } \\
\text { Değerlendirmesi }\end{array}$ \\
\hline Kalabalık yerel iş̧̧i toplulukları. & Kalabalık yerel işçi toplulukları sayısında azalmaya gidilmesi. \\
\hline $\begin{array}{l}\text { Projede her çalışan için sağlık taraması vb. } \\
\text { uygulamalar hakkında bilgi bulunamamıştır. }\end{array}$ & Projede her çalışan için düzenli PCR testi uygulaması. \\
\hline $\begin{array}{l}\text { Stajyer ve mimarlık öğrencilerin kabulü ile en az } 1 \text { ay } \\
\text { alanda çalışma. }\end{array}$ & $\begin{array}{l}\text { Stajyer ve mimarlık öğrencilerinin kabulü ile } \\
\text { alanda çalışılan gün sayısında azalmaya gidilmesi ve her } \\
\text { gelen stajyer ve mimarlık öğrencisi için PCR test zorunluluğu. }\end{array}$ \\
\hline $\begin{array}{l}\text { Sosyal mesafe ve hijyen uygulamaları hakkında bilgi } \\
\text { bulunamamıştır. }\end{array}$ & Sosyal mesafe ve hijyen uygulamaları. \\
\hline Lise öğrencilerinin 2 haftalık deneyim gezileri. & $\begin{array}{l}\text { Lise öğrencileri için deneyim gezileri yerine } \\
\text { online görüşmelerin sağlanması / sağlanamıyor ise } \\
\text { video kayıt düzeneği ile bilgilendirme. }\end{array}$ \\
\hline Çeşitli konularda gerçekleşen analiz ve çalışma atölyeleri. & $\begin{array}{l}\text { Çeşitli konulardan gerçekleşen analiz ve } \\
\text { çalışma atölyelerinin online olarak gerçekleştirilmesi/ } \\
\text { internet sağlanamıyor ise açık mekanın tercih edilmesi, açık } \\
\text { mekan tasarımlarının oluşturulması. }\end{array}$ \\
\hline Var olan finansal destekler. & Var olan finansal desteklerin arttırılması ve çeşitlenmesi. \\
\hline
\end{tabular}

Hijyen için gerekli malzeme hakkında bilgi bulunamamıştır Hijyen için gerekli malzemelerin konumlandırılması (Dezenfektan, (Dezenfektan, maske, eldiven vb.). maske, eldiven vb.). 
Oluşturulan bu çizelgeye göre; vernaküler mimaride kolektif çalışma esnasında kalabalık yerel işçi topluluklarına yer verilirken, pandeminin varlığı ile topluluğa katılan kişi sayısını azaltmaya yönelik çalışmaların yapılması gerektiği düşünülmektedir. Projeye dahil olan bireyler için kronik hastalıklar vb. gibi sağlık problemlerini öne süren bir çalışma hakkında bilgiye ulaşılamamış, COVID-19 sonrasında toplu çalışmalara dahil olacak bireyler için düzenli PCR testi önerisi sunulmuştur. Proje gelişim ve yönetim aşamasında, stajyer ve mimarlık öğrencilerinin sahaya kabulü sağlanıyorken, salgın hastalık sonrasında stajyer ve mimarlık öğrencilerinin kabulü hakkında alanda çalışılan gün sayısında azalma önerisi sunulmuştur. Bu öneriye ek olarak gelen her stajyer ve mimarlık öğrencisi için PCR test zorunluluğu getirilmesi gerekmektedir. COVID-19'un varlığı ile gündeme gelen sosyal mesafe kavramı, tasarım ve yapı sürecinde yer almamış ve hijyen uygulamaları hakkında yeterli bilgiye ulaşılamamıştır. Bunlara istinaden, pandemi süresi boyunca çalışmanın sürdürülebilirliğini sağlamak amaçlı sosyal mesafe ve hijyen tedbirleri getirilmelidir. Lise öğrencileri için sağlanan deneyim gezileri yerini online görüşmelere almalı, alt yapı eksikliğinden kaynaklanan bir problem görüldüğü taktirde video kayıt sistemi ile bilgi aktarımı sağlanmalıdır. Tasarım süreci gerçekleşirken yapılan bazı analiz ve çalışma atölyelerin gerçekleşmesinde mümkün olduğunca teknolojiden yararlanılması gerektiği üzerinde durulurken, alt yapı eksikliğinin kendini gösterdiği bölgelerde tercih edilen mekanların açık mekân olması, kısıtlı kişi sayısı ve hijyen önlemleri gibi uygulamaların yapılması gerekliliği belirtilmiştir. Ayrıca hijyen için gerekli malzemelerin tedariki ve konumlandırılması sağlanmalıdır.

Pandemi sürecinde, yapının inşasının sürdürebilirliği yanında, kolektif çalışmanın gerçekleştirip gerçekleştirilemeyeceği bu araştırma ile tartışılmakta olup, tüm uygulamalar ve kısıtlamalar ele alınarak, öneriler sunulmuştur. Vernaküler mimaride kolektif çalışma sürdürebilirliğini sağlayacağı bir kesinlik taşımasa da çalışmaya dahil olan her bireyin gerekli kuralları uygulaması durumunda mümkün kılınabileceği düşünülmektedir.

\section{Teşekkür ve Bilgi Notu}

Makalede araştırma ve yayın etiğine uyulmuştur. Çalışmada etik kurul izni gerekmemiştir.

\section{Yazar Katkısı ve Çıkar Çatışması Beyan Bilgisi}

Makalede tüm yazarlar aynı oranda katkıda bulunmuştur. Herhangi bir çıkar çatışması bulunmamaktadır.

\section{Kaynaklar}

Alaç, A. E. (2013). Kolektif çalışma (İ̧̧ birliği) becerisi. Buçak, M.; Dağlar, M.; Doğan, E. ve Harmancı, F. M. (Ed.), Güvenlik sektöründe operasyonel yöneticilik içinde (s. 137-152). İstanbul: Nobel Yayınevi. Erişim Adresi: https://www.researchgate.net/publication/346658872_KOLEKTIF_CALISMA_ISBIRLIGI_BECERI SI_2013_Alac_AE

Arslan, I. ve Karagül, S. (2020). Küresel bir tehdit (COVID-19 salgını) ve değişime yolculuk. Üsküdar Üniversitesi Sosyal Bilimler Dergisi, 10, 1-36. doi:10.32739/uskudarsbd.6.10.67.

Aytis, S. ve Ozcam, I. (2010, Nisan). Gelenekten geleceğe mimarlık. VI. Uluslararası Sinan Sempozyumunda sunulan bildiri, Trakya Üniversitesi, Edirne. 376-383. Erişim adresi: https://www.researchgate.net/publication/331356982_Gelenekten_Gelecege_Mimarlik

Ertaş, B. S. ve Bekar, i. (2020). Functional performance after re-use in traditional houses. Christov vd. (Ed.), Advances in scientific research: engineering and architecture (s. 418-428) içinde. St. Sofia: Klıment Ohrıdskı Unıversıty Press.

Bektaş, C. (2001). Halk Yapı Sanatı. İstanbul: Literatür Yayıncılık, 21-29.

B.C. Architect and Studies. (2012a). The Library of Muyinga. Erişim adresi:http://architects.bcas.org/Library-of-Muyinga

B.C. Architect and Studies. (2012b). Library of Muyinga Dropbox Arşiv. Erişim adresi: https://www.dropbox.com/sh/nktklxh4m34kzwo/AAD56QXI_oPc2JzIIYSyTJ4Ua 
B.C. Architect and Studies. (2012c). Library of Muyinga: A Community Project. Erişim adresi (23.04.2021): http://studies.bc-as.org/Library-of-Muyinga-a-community-project

Canan, F., Kobya, H. B., Aköz, A. B. ve Temizci, A. (2020). Vernaküler ve çağdaş mimarlık örneklerinin sürdürülebilirlik bağlamında karşılaştırmalı analizi: Antalya Kaleiçi ve Deniz Mahallesi örneği. Süleyman Demirel Üniversitesi Fen Bilimleri Enstitüsü Dergisi, 24(2), 256-266. doi: 10.19113/sdufenbed.651622.

Eyüce, A. (2005). Geleneksel yapılar ve mekanlar. İstanbul: Birsen Yayınevi, 2.

Hasol, D. (2014). Ansiklopedik mimarlık sözlüğü. İstanbul: Yem Yayın, 491.

Janetius, S. T. (2020). Chapter Five Indigenous, Vernacular Architecture, Architectural Psychology: Space, Psyche, Enigma \& Symbol. Architectural Psychology: Space, Psyche, Enigma \& Symbol Mishil \& Js Publisher, Thrissur, 53-59. Erişim adresi: https://www.researchgate.net/publication/340925602

Kavas, K.R. (2015). Environmental Anesthesia and false vernacular architecture: The case study of the Western Taurus Mountains. Suna-inan Kıraç Akdeniz Medeniyetleri Araştırma Enstitüsü Yıllık Dergisi, 18, 325-343. Erişim adresi: https://dergipark.org.tr/en/pub/adalya/issue/54563/743571\#article_cite

Kolektif ne demek?. (2020). Erişim adresi: https://turkcenedemek.com/kelime/kolektif/

Kolektif yaşam nasıl olmalı?. (2020). Erişim adresi: https://www.iienstitu.com/blog/kolektif-yasamnasil-olmali

Paköz, A. E. (2017). Vernaküler ve bağlantılı kavramlar kapsamında Türkiye'de mimarlık (Doktora tezi. Mardin Artuklu Üniversitesi, Mardin). Erişim adresi: https://tez.yok.gov.tr/UlusalTezMerkezi/tezDetay.jsp?id=Y_TVZqSf3zNyHfGRvue_PA\&no==IF0 CIZEEVzYd4vsAp9QhZA

Sezgin, H. (1984). Vernaküler mimari ve günümüz koşullarındaki durumu. Mimarlık Dergisi, (22)3-4, 4447.

Şen, N. (1968). Anonim mimaride çeşitlilik deneme I. İstanbul: iTÜ Yayıncılık.

Şuta, O. (2019). Vernaküler mimari bağlamında gölcük yazlık ılıcası turizm yapıları. Social Mentality and Researcher Thinkers Journal, 5(18), 612-634. doi:10.31576/smryj.257.

Terkol, G. (2008). Günümüz sanatında kolektif üretim biçimleri (Yüksek lisans tezi, Yıldız Teknik Üniversitesi, İstanbul). Erişim adresi http://dspace.yildiz.edu.tr/xmlui/bitstream/handle/1/6588/0041433.pdf?sequence=1\&isAllow ed $=\mathrm{y}$

TDK. (2021). Türk Dil Kurumu. Erişim adresi: https://sozluk.gov.tr/

Yeler, G., Özek, V. (2007, Nisan). Geleneksel konut mimarlığının biçimlenişinde iklim faktörünün değerlendirilmesi. Ekolojik Mimarlık ve Planlama Ulusal Sempozyumunda sunulan bildiri, Mimarlar Odası Antalya Şubesi, Antalya. 